\title{
Emmanuel Levinas: Hermeneutics, Ethics, and Art
}

\author{
Hanoch Ben-Pazi \\ Kibbutzim College of Education, Tel Aviv, Israel \\ Bar Ilan University, Ramat-Gan, Israel
}

\begin{abstract}
This article draws attention to the subject of art in Levinas's thinking through consideration of his philosophical language, which is aided by images, metaphors, and idioms of art. The primary image that will accompany our discussion throughout this article is the image of art as shadow, which Levinas incorporates into the title of the essay which he devotes to the subject of art: "Reality and Its Shadow". Thinking about art from the perspective of Levinas means thinking about image and essence, about which is visible before us and which we cannot see, and about the different ways in which art can express itself. Levinas's theory of interpretation is grounded in and guided by the field of ethics and addresses the ethical aspects of interpretation. Levinas approaches the discourse of interpretation not out of naïveté but rather based on a deep understanding of the field of hermeneutics, with all its shortcomings and challenges. Thinking of hermeneutics from an ethical perspective is no mere addition to the discussion but the very crux of the matter. An attempt to understand interpretation as an act of exposing the truth encounters serious philosophical and logical difficulties, whether we are seeking to discover the intention of the artist, the intent of a specific work of art, or a hidden form within the work itself. The engagement with Levinas's theory of hermeneutics, however, raises a different question which is the focus of this article: Can Levinas's theory of interpretation be applied to the realm of artistic creation, and if so, how? This question is sharpened by the difficulties that Levinas himself poses to his readers by designating art as the "shadow" of reality and drawing attention to the egoistic dimension of the artistic act.
\end{abstract}

Keywords: Emmanuel Levinas, hermeneutics, ethics, art, Jewish philosophy, phenomenology

\section{Introduction}

"Art does not know a particular type of reality; it contrasts with knowledge. It is the very event of obscuring, a descent of the night, an invasion of shadow" (Levinas, 1989, p. 132). Levinas chooses these words to depict the role, action, and essence of art. Terms such as "obscuring”, "descent of the night", and "shadow" serve as modes of a consciousness that is different from, if not the opposite of, "enlightened” knowledge, which is signified, in contrast, by terms such as "light" and "revelation". This article draws attention to the subject of art in Levinas's thinking through consideration of his philosophical language, which is aided by images, metaphors, and idioms of art. The primary image that will accompany our discussion throughout this article is the image of art as shadow, which Levinas incorporates into the title of the essay which he devotes to the subject of art: "Reality and Its Shadow".

The metaphor of art as shadow, or, more precisely, as a shadow of reality, proves helpful in its ability to cause us to think about reality as amenable to allegory and as a gateway into a discussion of art and artistic

Hanoch Ben-Pazi, Senior Lecturer, Kibbutzim College of Education, Bar Ilan University. 
interpretation. Indeed, Levinas's treatment of art encompasses aesthetic questions regarding its role and its meaning, the language and languages of the arts, the meaning of artistic expression, and the prospect that art is merely the shadow of reality. In addition to the issue of aesthetics, Levinas's approach to art draws attention to art's ability to withdraw into itself; the ways in which art takes part in, or refrains from taking part in, social activity; and the ethical question of interpretation and its boundaries. This article attempts to reconsider the place of art in the philosophy of Levinas, with a focus on the hermeneutical question with relation to art.

Thinking about art from the perspective of Levinas means thinking about image and essence, about that which is visible before us and that which we cannot see, and about the different ways in which art can express itself. "The function of art is expression” (Levinas, 1989, p. 130), asserts Levinas, employing a generalization reflecting a substantial element of dogmatism. Art, however, expresses itself in different ways, speaks in different languages, and employs different modes of expression. "An artist-even a painter, even a musician—tells. He writes of the ineffable” (Levinas, 1989, p. 130). For Levinas, works of art are not merely a means of expression. They invite us to continue onward to which lies beyond what is visible (in the common sense of the word): "An artwork prolongs, and goes beyond, common perception", writes Levinas. "What common perception trivializes and misses, an artwork apprehends...” (Levinas, 1989, p. 130).

Art is intended to capture the "irreducible essence" (Levinas, 1989, p. 130). Although we ascribe to the artist (and to art itself) exceptional faculties of expression and different creative means of expression, do we also wish to credit him with the capacity for "metaphysical intuition"? At times, when the common language is unable to speak, we find the work of art-the song, or the painting - to be a mode that enables us to express ourselves. And sometimes, we even find ourselves proclaiming that a work of art "is more real than reality". Such sentiment, maintains Levinas, "attests to the dignity of the artistic imagination, which sets itself up as knowledge of the absolute” (Levinas, 1989, p. 130). But here we encounter a challenging notion: Artwork's capability to express the inexpressible is indicative of recognition of the status of reality-not revealed reality but that which is exalted and which is neither exposed nor visible. "...Realism nevertheless retains all its prestige", writes Levinas. "In fact it is repudiated only in the name of a higher realism. Surrealism is a superlative” (Levinas, 1989, p. 130).

Beyond Levinas's attitude toward art and aesthetics, this article also considers the interpretation of art within the field of ethics - that is to say, the role of different acts of art as modes of creation and performance located within, and in relation to, ethical thought. The notion that art must be thought of within the field of ethics, and in relation to the ethical context, is not self-evident and actually runs counter to the prevalent conception of "ethical art" as "mobilized art" possessing suspect artistic qualities. Indeed, many people maintain that art must be evaluated using the tools of art alone, that is, by answering questions such as "is the work aesthetically pleasing?" Or "is it interesting?” We may therefore assume that the tendency will be to decline ethical questions regarding art and to consciously refrain from judging works of art in accordance with their ethical merit. In artistic discourse, ethical concerns emerge, quite by definition, as questions of boundaries. That is to say, when an artistic work or performance exceeds a certain ethical boundary, they are subject to ethical limitations originating from outside the artistic field.

Levinas's theory of interpretation is grounded in and guided by the field of ethics and addresses the ethical aspects of interpretation. ${ }^{1}$ Levinas's philosophy produces an ethical discourse of responsibility that seeks to

${ }^{1}$ For an extensive presentation of Levinas's theory of interpretation, see Ben-Pazi (2012); Meir (2002-2004), pp. 53-70; Cohen (2001). 
establish the subject and his consciousness of subjectivity by giving precedence to and elevating the Other, whose face he encounters. Examination of the realm of hermeneutics and the techniques of interpretation in Levinas's writings reveal the question of interpretational motivation, the approach to artistic creation, and the rules of interpretation applied to it as situated within ethical discourse and functioning in accordance with a strict ethical expectation. Levinas approaches the discourse of interpretation not out of naïveté but rather based on a deep understanding of the field of hermeneutics, with all its shortcomings and challenges. ${ }^{2}$

Thinking of hermeneutics from an ethical perspective is no mere addition to the discussion but the very crux of the matter. An attempt to understand interpretation as an act of exposing the truth encounters serious philosophical and logical difficulties, whether we are seeking to discover the intention of the artist, the intent of a specific work of art, or a hidden form within the work itself. Levinas takes part in the ongoing hermeneutical philosophical discussion and proposes solutions to major difficulties in the theory of interpretation by relocating the issue of interpretation to the field of ethics. The interpreter's ethical obligation both to his listeners and to the content he articulates provides a thorough solution to the fundamental problems of hermeneutics. The engagement with Levinas's theory of hermeneutics, however, raises a different question which is the focus of this article: Can Levinas's theory of interpretation be applied to the realm of artistic creation, and if so, how? This question is sharpened by the difficulties that Levinas himself poses to his readers by designating art as the "shadow" of reality and drawing attention to the egoistic dimension of the artistic act. ${ }^{3}$

In order to structure and validate this article's ethical-interpretive argument, I begin with two prefaces that will serve as two important layers of our discussion. The first emphasizes the relationship between ethics and aesthetics and the tension that exists between these two realms. The second presents a broad view of the phenomenon of interpretation in Levinas's thinking and of the ethical meaning he ascribes to the interpretative field. Together, these prefaces serve as a foundation for a discussion of the hermeneutics of the arts from Levinas's perspective and of the manner in which he contends with the ethical dimension of art. For this reason, readers may also reverse the order of reading by beginning with the hermeneutics of art and only then returning to the two building blocks that make it possible to sustain Levinas's ethical position.

\section{Between Ethics and Aesthetics and the Dilemma of Job}

At first glance, it appears that the realm of ethics and the realm of aesthetics constitute two separate subjects in philosophy and that questions pertaining to what is proper from an ethical perspective on the one hand, and what is aesthetically pleasing on the other hand, belong to two distinct vocations. We would like to assume that these two realms converge and find common language in the field of metaphysics. However, thorough consideration reveals that these two realms can at times collide with one another, and that what is pleasant to behold is not always virtuous, and that what is virtuous is not always pleasant to behold.

To clarify the tension between these two realms, we are aided by the Book of Job and the interpretive and ethical questions it raises. Theoretically, the Book of Job revolves around the ethical, or ethical-theological question of theodicy, or the justification of God. But reading the Book of Job and considering its aesthetics also brings us face to face with another question: the question of aesthetics. The ethical and aesthetic horizons of

\footnotetext{
${ }^{2}$ For extensive surveys on the field of hermeneutics, see Muller-Vollmer (1989); Palmer (1969); Ebeling (1959), pp. 243-262; Iser (1978); see also Levy (1986); Levy (2006); and Levy (1976).

${ }^{3}$ On art in the philosophy of Levinas, see the following works by Levy (1996); Levy (1990); Soutet et al. (2010); Atterton (2007); Herzog (2005).
} 
discussion vis-à-vis the Book of Job produce tension between these two realms which is at times impossible to bear.

The Book of Job may constitute the Bible's most significant discussion of ethics. However, what is surprising about the role of this book is the fact that its influence on the evolution of religions, philosophy, the plastic arts, literature, and theatre has been much greater than its influence on ethics. ${ }^{4}$

On the one hand, the Book of Job raises an ethical question and protest as the book in which man calls God to task regarding the meaning of justice and the existence of unjustified evil in the world. ${ }^{5}$ On the other hand, it is one of the most poetic and beautiful books of the Bible. Job explores the ethical significance of human life and contends with the question of whether the religious explanation can provide a satisfactory vindication for the non-ethical manner in which nature operates and human life is conducted. The different positions advanced in this discussion are as follows: an understanding of suffering as an outcome of, and punishment for, the sins of the sufferer; an understanding of man as being tested; recognition of the limits of consciousness; and the religious meaning of "the world works in its own way" (Leibowitz, 1974; Leibowitz 1995; Leibowitz, 1975). But God's response to Job does not belong to this ethical discussion and, in a sense, is no less cryptic than the book as a whole, and perhaps even more so. "Where were you when I laid the earth’s foundations?” God asks Job from out of the whirlwind. Do you know how to stretch a measuring line across it? Do you know how to drown the masters of the land? Do you know how to listen to the chorus of the morning stars? You should know - Job - that the children of God watching you applaud and cheer, but not only do you not know this, you do not even know how to appreciate it. God does not accept Job's ethical challenge and instead launches into a lengthy posing of two questions, which can be referred to generally as "Do you know?” and "Can you?” Do you know everything? What, at all, can you do? Can you entertain yourself with Leviathan or with Behemoth?

In a brief yet packed article, Addy Zemach proposes a substantial challenge to the interpretation of God's response in the Book of Job (Zemach, 1989). According to Zemach's analysis, the best way to understand God's response is to detach it from the theological and ethical realm and to consider it in the realm of aesthetics (Haezrachi, 1954; Haezrachi, 1961). God's response to Job reveals that although Job’s suffering has no moral justification, it has justification rooted in a different language: the language of aesthetics. Put simply, God's words can be understood as conveying the following message: "Job-You may think that the world in which you live operates in accordance with the goodness and morality within in it. You should know, however, that I run the world based on aesthetic logic" (Zemach, 1989). That is to say, man must admit that even if the world does not operate in an ethical manner, it is extremely impressive from an aesthetic perspective. And not only is it aesthetic, but the most aesthetic things are also quite often the cruelest. "Therefore”, God explains to Job,

if you want to judge me ethically, you should know that the list of my sins is much longer and concerns contexts that you have not even considered, such as the wild horses that gallop forward unaware of whether they have trampled someone to death in the process; the lioness who is able to feed her cubs only after killing her prey; and rain that falls in the desert, with no overt purpose. None of these things are morally justified, but they all have aesthetic justification. (Zemach, 1989, p. 15)

\footnotetext{
${ }^{4}$ On the place of the Book of Job in the arts, see Mazor (1995); Revel-Neher (1995); Perry-Lehmann (1992).

${ }^{5}$ As the scope of this work precludes us from presenting a survey of the ethical philosophical writing on the Book of Job, we limit ourselves to a list of a few of the important articles on the subject, as well as Phillippe Nemo's book, for which Levinas wrote an introduction. See Nemo (1998); Margarete Susman, Das Buch Hiob und das Schicksal des jüdischen Volkes (the Book of Job and the fate of the Jewish people) (Zürich, 1946); Nordmann (1993); Kröger (2004); Ueckert (2000); Ueckert (1991); Delf (1993); Malagoli (1950).
} 
They are fascinating and impressive and cause people to make their way to the ends of the earth to elicit a cry of wonder and elation.

The literary and poetic usage of the Book of Job serves the argument regarding the tension between the realms of aesthetics and ethics. Aesthetics and ethics are two distinct realms, two fields of thought with two different and separate internal hierarchies of principles that are at times contradictory and at other times compete with one another. Not everything that is good is beautiful, and not everything that is beautiful is good. Sometimes, the beautiful is not good, whereas that which is good appears ugly in aesthetic terms. Classical Greek thinking sought to portray beautiful and good as one joint hierarchy, because the beautiful is also harmonious and the good reflects harmonious balance. The biblical reality, and, in a very manifest and clear sense, the reality with which we are familiar from modern thinking, relate to these two scales as separate from one another. As a result, we can consider a brutal occurrence and say that it is beautiful, or at least impressive.

To make the questions raised in the Book of Job more relevant to the world of the twenty-first century, we follow the lead of Slavoj Žižek and consider the temptation of observing the harsh, violent reality of today. Our eyes refuse to turn away from the disturbing images that appear on our television screens, such as the toppling of the Twin Towers on September 11th (Žižek, 2002; Baudrillard, 2012). Our gaze returns to the screen over and over again to view the images of the disaster caused by the Tsunami that brutally struck the coast of Japan, flinging massive ships onto shore. We like to think of man as being guided by ethical considerations, but we cannot deny the existence of aesthetic guidance. In this manner, it may be the case that man is guided by aesthetics no less than by ethics, and, taken to the extreme, that things are sometimes beautiful and impressive precisely because they are ethically inexcusable. Using the terminology of interpretation, we can point to possible tension between ethical interpretation and aesthetic interpretation. Interpretation can be ethical and unpleasant, or, on the contrary, it can be pleasant but nonetheless emerge as unethical.

\section{The Ethical Path to Interpretation}

This second part deals with the ethical significance of hermeneutics from the perspective of Levinas. Hermeneutical discourse is meant to clarify and structure interpretive motivation and the different ways of interpreting and clarifying-whether we are engaged in an attempt to understand the intention of the author; tools we can use to understand the author better than he understood himself; the notion that we can identify what it is that the reader, the text, and the author have in common; identification of the fundamental structures before and after the work; exploration of the margins of the work to illuminate its deeper layers; or the possibility of allowing the work to speak for itself. Levinas takes part in hermeneutical philosophical discourse and draws attention to the logical and epistemological difficulties of the act of interpretation. For Levinas, the approach that understands interpretation as an act of exposure of a known or unknown internal or external truth runs into serious philosophical and logical difficulties.

Considering interpretation in the ethical context also enables us to address one of the greatest challenges of hermeneutics, ${ }^{6}$ which can be concisely summed up as follows: An artwork is always located within a context, that which emanates outward from the artist toward the person interested in his work. The interpreter, therefore,

\footnotetext{
${ }^{6}$ Levinas's solution to this problem, that of emphasizing the importance and the precedence of the Other, is more than just an interesting notion and an appealing ethical statement. It also has the potential to solve some of the major problems of this realm by shifting the focus to relationships between the I and the Other. The meaning with which he imbues these relationships not only makes an ethical position possible but provides a solution to the epistemological questions.
} 
does not interpret the work for himself but rather seeks to mediate the work and interpret it to, and for, an Other. As far as Levinas is concerned, the understanding that interpretation occurs within the framework of relationships between people teaches us that ethics not only demarcates the limits of interpretation but that interpretation is, from the outset, located in the ethical field. This awareness charges the interpreter with ethical responsibility toward the author, the future reader, and the community of interpreters.

In order to take one more step into Levinas's theory of interpretation, we draw attention to Levinas's significant distinction between the dimension of "the saying" (le dire) and "the said" (le dit). Explained generally, the saying is the living dimension of speech — that cannot be contained within fixed, closed themes and concepts, and that exists between people who are speaking. The said, in contrast, is the frozen, immobilized dimension: the introduction of living ideas into frameworks of fixed terms and rules. We can get a better sense of this differentiation by applying it to the distinction between speaking and the written word. Speaking preserves the living dimension that continues to exist between people who are talking, whereas the transition into writing represents the immobilization to which words are subject when they are condemned to eternal existence in the form of permanent letters. This distinction also assists Levinas in distinguishing between the oral law and the written law in Jewish tradition. The oral law is characterized by frequent change, stemming from the vitality of the interaction between people. Jewish written law, or the Torah, on the other hand, is that which is closed and cannot change, that which reflects the extent to which it is not dependent on people and can endure for generations.

A picturesque example of this position is found in part of the discussion between Socrates and Phaedrus in the Platonic dialogue The Phaedrus. In this text, speaking, with its living and growing character, is preferred to writing, which is regarded as a process of putting to death. Plato goes further by maintaining that writing misleads the reader, and that its works "have the attitude of life, and yet if you ask them a question they preserve a solemn silence” (Plato, 1993, p. 88). The reader imagines that the book speaks out of intelligence, when in reality it answers all questions with the same answer. "And when they have been once written down they are tossed about anywhere among those who do and among those who do not understand them" (Plato, 1993, p. 88). The written text eradicates the living nature of speech. Writing engenders a process of alienation, and the text is subject to oblivion the moment it is put down in engraved or printed words.

Speaking, posits Plato, is comparable to sowing ideas within the soul from which words of knowledge can spring forth - words that can defend themselves and that continue to live even after they are sown, that "are not unfruitful, but have in them seeds which may bear fruit in other natures, nurtured in others ways-making the seed everlasting and the possessors happy to the utmost extent of human happiness” (Plato, 1993, p. 89). The role of interpretation, therefore, is to try to return to the person who sowed the seeds in "water with pen and ink", or to go beyond this "husbandman" and to learn something about the society and culture in which he acted.

Levinas seeks to demarcate a new path in hermeneutical thought that allows man to go beyond himself in respect for and for the sake of the Other. The limitations of writing enable the said text to open up to new worlds of meaning, and to the many living and breathing spoken dialogues that will occur and continue to occur between the reader and the written words before him, between the reader and other readers, and even between the written text and the critique articles, studies, and surveys that pertain to it. When the hermeneutical dialogue is planted in the field of ethics, writing emerges as a nurturing and blossoming process which, by means of the ever growing number of interpretations, creates movement far beyond itself. 
When I think of a text, I can imagine the thoughts and speech that preceded its composition. The written text contains clear indication that it was preceded by a saying, the living text. Equally as important, however, is the fact that the said, the written text, also contains traces of the saying. The living, conscious words continue to echo within the frozen dead terms, words, and letters. Even after its immobilization, the text preserves its living foundations, which can be brought back to life by the interpretation that is assigned to the written text. In this way, our readers of the written text resuscitate the living essence that continues to live on within it, even after it is frozen and immobilized within dead letters.

This process can be carried out in a destructive manner that introduces the "new" - the information located before the subject-into the world of the terms and concepts of the subject through "phenomenological reduction", which constitutes a contending with the act of identification- "le meme", or "the same”. Levinas's call is a call to overcome the fear of that which lies beyond the I, beyond the subject, by incorporating it and identifying it in terms and concepts that are perceived by the I. His apprehensions regarding interpretation stem from concern regarding the potential incorporation of the Other into the I, the immobilization of the saying within the static, frozen state of his or her concepts. This concern is also of an ethical nature, as the Other does not give himself to the concepts of the I. Likewise, the text does not give itself to the interpretation applied to it. All that can be said, with humility, is that the text calls upon the reader to read it. Ethical interpretation does not aim to recreate the text's past, the saying that preceded the said, but, on the contrary, seeks to take the text onward, to the living dimension that does not yet exist and has yet to be revealed within it. The ethical act opens up the text to the Other, to new readers. Using the terminology of the tenses of time, we can say that interpretation does not represent a return to the past in order to recreate the intention of the author or some original meaning it contained. It is also not conjecture in the present based on a reduction of the text into concepts of the present I. Interpretation breathes new life into the text by directing it toward the future. This turn toward that which does not yet exist in the present can occur only through the encounter with the Other, which imbues the I with aspects and horizons that were hitherto unknown to him. The role of interpretation, therefore, lies in the ability of the interpreter to venture outside himself toward the other. Interpretation strives not to rediscover the text but rather to open it up to the Other. Ethical interpretation, therefore, is advantageous not only in its ability to convey an ethical message but also in its ability to breach the circle of the return to the past, or the return to itself.

\section{The Question of Artistic Interpretation}

The question of interpretation reemerges once again in the context of aesthetics. According to Levinas, aesthetics is inseparable from ethics, which requires us to enhance the tools of artistic judgment within the ethical discussion. In one of the few articles which he dedicated to the subject of art, Levinas expresses the concern that art leaves man alone with himself. "There is something wicked and egoist and cowardly in artistic enjoyment” (Levinas, 1989, p. 142), he writes, leaving us to contend with the question of whether artistic creation is indeed an egoistic action. Is the act of artistic creation a reentry into "the cave"? Despite its appearance as a vital, living act, we might ask ourselves, isn't it actually just a process of immobilizing and killing? Can we think of art and artistic creation as an interaction between two people? Can art be understood and interpreted as an act of dialogue and inspiration?

Interpretation pertaining to the act of artistic creation bears obligation toward the artist, whether alive or deceased, as well as ethical obligation toward its listeners and readers and toward that which can be born of the 
interpretation assigned to the work of art. Levinas's great departure from the possibility of saying absolutely anything in interpretation is based on a deep understanding that the act of interpretation takes place in the realm of interpersonal relations and is therefore located in the field of ethics. From this perspective, the act of artistic creation and the act of interpretation (artistic interpretation as well) encompass the subject's responsibility for the future interpretation of his words. Levinas's subject cannot simply invoke artistic or interpretive freedom, as he bears responsibility for his interpretation.

\section{The Living and Dead Aspects of the Act of Artistic Creation}

Levinas is concerned by the immobilizing dimension of art, that is, by the artistic process that immobilizes the living entity, thereby bringing about its death. Does art truly immobilize the vitality of reality within a work of art? If Levinas is concerned with writing's power to fix the living saying within the lifeless said, then he is certainly concerned about art's power to fix the living person within the "form" or "mask." Levinas expresses concern not only that the artistic creation lacks a living future but also possibly a living present.

To say that an image is an idol is to affirm that every image is in the last analysis plastic, and that every artwork is in the end a statue - a stoppage of time, or rather its delay behind itself...the artwork does not succeed, is bad, when it does not have that aspiration for life which moved Pygmalion. But it is only an aspiration... a caricature of life. (Levinas, 1989, p. 138$)^{7}$

Literature, maintains Levinas, is a forgery or illusion, and is therefore unethical. Art, moreover, seeks to be an enchantment of reality, a sorcery of sorts (Eaglestone, 1977, p. 142). Can art preserve a transcendent dimension through aesthetic means? Is art not the process that produces the mask that conceals the responsibility of the artist? To what extent does art preserve life and to what extent does it imprison it within material?

Levinas uses the term "shadow" to characterize art within the intriguing title "Reality and Its Shadow". He appears to have drawn this metaphor from the allegory of the cave. An allegory, he explains, "is an ambiguous commerce with reality in which reality does not refer to itself but to its reflection, its shadow...An image, we can say, is an allegory of being" (Levinas, 1989, p. 135). But are we using the term "shadow" solely as a metaphor? We must show the manner in which we use the term "shadow" and the meaning we ascribe to it. We must show where this side, about which we are speaking, is located. Even if we try to understand this shadow as an extension of the thing in reality, including its inertia and persistence, or, alternatively, the dimension of death that exists in the shadow of reality, we must still first clarify "the ontological signification of materiality itself” (Levinas, 1989, p. 137). “The phenomenology of images”, explains Levinas,

insists on their transparency. The intention of one who contemplates an image is said to go directly through the image, as through a window, into the world it represents... Yet nothing is more mysterious than the term "world it represents"- since representation expresses just that function of an image that still remains to be determined. (Levinas, 1989, p. 134)

If we sought to characterize the original, ethical language as a face-to-face encounter without representation, as the language that is made possible by ethics, by the voice and the revelation of the Other, aesthetics produces a representation of reality and, by doing so, conceals it. More than that, however, it

\footnotetext{
${ }^{7}$ See also from Levy (1996), p. 50.
} 
conceals the voice of the Other. ${ }^{8}$ In this manner, explains Levinas,

The idea of shadow or reflection to which we have appealed—of an essential doubling of reality by its image, of an ambiguity "on the hither side" - extends to the light itself, to thought, to the inner life. The whole of reality bears on its face its own allegory, outside of its revelation and its truth. (Levinas, 1989, p. 136)

An image, holds Levinas, differs from a sign, a word, or a symbol in its goal of "resembling”, which it directs at its object. The image ostensibly stops within itself and does not return to the reality it resembles. Reality can only be compared to its artistic image as part of the artistic discussion itself. However, because of works of art, reality cannot remain simply reality but contains the dual dimensions of reality and shadow, of the visible and the image. " "Being is not only itself", Levinas continues,

it escapes itself. Here is a person who is what he is; but he does not make us forget, does not absorb, cover over entirely the objects he holds and the way he holds them, his gestures, limbs, gaze, thought, skin, which escape from under the identity of his substance, which like a torn sack is unable to contain them. (Levinas, 1989, p. 135)

Levinas's deep concern, then, appears to be not with art but rather with art created only for art's sake, artworks created only for the sake of creation, and the egoist dimension of the process of artistic creation: "There is something wicked and egoist and cowardly in artistic enjoyment" (Levinas 1994, p. 142; Levy, 1996, p. 50). The ethical judgment spoken of by Levinas is not related to the outcome of the artistic act but the mode of the act of artistic creation. Levinas seeks not to discuss the work in a manner similar to Sartrean judgment, which judges works of art solely according to their cultural contribution. He seeks, rather, to investigate the power of art and the extent to which it is committed to reality and life. On this basis, he also seeks to examine the role of interpretation with relation to art, which receives its vitality from ethics.

The fear of confinement within aesthetic language and the shadow that art casts, which can conceal reality and man's responsibility in reality, enables us to better understand the meaning of interpretation. Art has the power to close off, but also to discover and to draw attention to the not said within the said. Art can stimulate the reverberation and the renewed saying in the heart and eyes of the reader and the observer.

\section{Art's Power to Inspire in Its Capacity as “More Real Than Reality”}

Another aspect of art concerning Levinas is its ethical power. For example, Levinas characterizes works of art as "more real than reality", explaining that they have the ability to convey more about reality than speech. On this issue, as in his other remarks relating to art, Levinas articulates Plato’s ambivalent attitude toward the field. Art has the ability to create emotion, which is a particular mode of deviation toward beyond presence. ${ }^{10}$

Here, I wish to draw attention to the manner in which Levinas uses art to advance his ethical philosophical arguments. On many occasions, when attempting to illustrate these ideas of vitality, essence, and reverberation and expression, Levinas makes reference to the subject of art. Although the example itself presents some

\footnotetext{
${ }^{8}$ Here, Eaglestone makes use of Donoghue's distinction between epi-readings and graphi-readings. An epi-reading is based on the desire to hear the absent person - the author-by means of the written word (Donoghue, 1981, p. 141). For an epi-reader, "language is transparent, a window through which the world of people, actions, and events can be seen" (Eaglestone 1977, p. 3; also see Donoghue 1981, p. 146). A graphi-reading, on the other hand, gives priority to language and the text, reading the words and refusing to move beyond them. Graphi-reading is unwilling to create a world behind the words, which are regarded as of the utmost importance.

9 See Levinas's account on this topic (Levinas 1989), pp. 132-135.

10 For a more extensive discussion, see Ophir (2005), pp. 224-249. Ophir's reading relies on Lyotard's studies of the aesthetic context of the sublime.
} 
problems, I draw attention to the meaning of the living and dead dimensions of the language of art which serve both to immobilize and stimulate life:

Art is the pre-eminent exhibition in which the said is reduced to a pure theme, to absolute exposition, even to shamelessness capable of holding all looks for which it is exclusively destined. The said is reduced to the Beautiful, which supports Western ontology. Through art essence and temporality begin to resound with poetry or song. And the search for new forms, from which all art lives, keeps awake everywhere the verbs that are on the verge of lapsing into substantives...In music sounds resound; in poems vocables, material of the said, no longer yield before what they evoke, but sing with their evocative powers and their diverse ways to evoke, their etymologies. (Levinas, 2011, p. 40)

But if it appears to us that the language, and certainly the language of aesthetics, fixes and immobilizes, Levinas responds by asserting that this is not all it does. The language of the plastic arts certainly has the effect of fixing and enclosing within concepts and patterns—of immobilizing the saying within the said. ${ }^{11}$ Nonetheless, he maintains, it does not do so completely; its meaning is not solely one of immobilization and closure. Language that says and fixes also contains, in itself, a measure of the "non-said" (non-dit), of that which remains unsaid in the said language. Therefore, the language of art does not completely immobilize "the living" within "the dead", the "saying" within the "said", but rather preserves within the said that which was not said, and in this way can also serve to inspire. The playing of a musical instrument provides a good metaphor for illuminating this notion. A musical instrument is a dead, plastic object, but its materiality is what enables it to be played, facilitating the introduction of a living element into a dead body. That is to say, although a musical instrument is made of a specific, defined material and is fixed within its own materiality, the fact that it is played facilitates a new openness of music and interpretation. Although Levinas uses this metaphor in the context of literature in general and sacred texts in particular, we can also propose viewing it more broadly as it relates to all works of art that inspire:

The cello is a cello in the sonority that vibrates in its strings and its wood, even if it is already reverting into notes, into identities that settle into their natural places in gamuts from the acute to the grave, according to the different pitches. Thus the essence of the cello, a modality of essence, is temporalized in the work. (Levinas, 2011, p. 41)

Perhaps a good example of this usage with regard to art is the manner in which Levinas relates to the poetry of Paul Celan:

For Celan also...the poem is the spiritual act par excellence. An act at once inevitable and impossible...Does he [Celan] not suggest poetry itself as an unheard of modality of the otherwise than being? The Meridian: "like speech immaterial, yet of the earth”. (Levinas, 1996, p. 46)

On this basis, at the conclusion of this article, I refocus our attention on language in its literary and philosophical sense. At the beginning of Beyond the Verse, Levinas poses a question about the different meanings of language and permits himself to ruminate not only about the social contexts of language but also about what is revealed within it. As far as he is concerned, language is not solely a means, not merely an implement for the conveyance of information or a linguistic tool for communication:

\footnotetext{
11 This position is not a simple one, as we will see below in a separate section discussing Levinas's understanding of the poetic and artistic meaning of literary reading. But we must already inquire into art's ability to not conceal reality and presence but actually to enhance it. See Ophir (2005), pp. 224-249. The foundations of the notion of the enhancing power of art are found in the thinking of Heidegger, Benjamin, and Lyotard. See Heidegger (2010), pp. 83-141; Benjamin (1969); Lyotard (2002); Sartre (2004). The same ambivalence can also be observed in Rosenzweig's approach to art. See Meir (2002).
} 
Language which has become Holy Scriptures, and which maintains its prophetic essence-probably language par excellence-the Word of God that is already audible or still muffled in the heart of every act of speech, is not solely a matter of the engagement of speaking beings in the fabric of the world and History, where they are concerned with themselves - that is to say, with their perseverance in being. In language a signified does not signify only from words which, as a conjunction of signs, move towards this signified. Beyond what it wants me to know, it co-ordinates me with the other to whom I speak; it signifies in every discourse from the face of the other, hidden from sight yet unforgettable: from the expression before words my responsibility-for-the-other is called upon, deeper than the evocation of any images, a responsibility in which arise my replies. (Levinas, 1994, p. xii)

Thus, despite Levinas's complex criticism of the artistic modes of expression which produce a shadow of reality, close themselves within an inner world, and distance themselves from the acceptance of ethical responsibility, we can also offer another meaning, one that resituates the arts within the discourse of responsibility. The image, the painting, and all acts of artistic creation, for that matter, can stem from the subject's response, as an ethical subject, to the voice addressing him from within reality or from the face of the Other (or Others). Such artistic creation can constitute a deep expression of the artist's acceptance of the responsibility he bears, and the expression this creation elicits can serve as an additional voice calling on the viewer and the listener to act with responsibly and ethically.

\section{Conclusion}

This article has examined Emmanuel Levinas's attitude toward the issue of art from the perspective of interpretation. Levinas defines hermeneutics as located first and foremost in the realm of ethics and as obligated in its interpretation to both the writer and the readers, as well as to the responsibility assumed by the interpreter by virtue of his or her interpretation. In this context, this article has explored the question of art within the field of hermeneutics.

In order to clarify the dilemma with which Levinas contends, I began by discussing the tension between ethics and aesthetics as reflected in the biblical book of Job, as well as the possibility of discussing works of art that are not ethical, or, in more extreme cases, works of art that run counter to ethics. The article proposed a number of significant aspects of the ethical questions that art faces, according to Levinas, and identified the elements of inspiration and responsibility that are reawakened by the artistic creation.

\section{References}

Atterton, P. (2007). Art, religion, and ethics post mortem Dei: Levinas and Dostoyevsky. Levinas Studies, 2, 105-132.

Baudrillard, J. (2012). The spirit of terrorism. (C. Turner, Trans.). London: Verso.

Benjamin, W. (1969). The work of art in the age of mechanical reproduction. In Illuminations: Essays and reflections. New York: Schoken.

Ben-Pazi, H. (2012). Interpretation as an ethical act: The hermeneutics of Emmanuel Levinas. Tel Aviv: Resling.

Cohen, H. R. (2001). Ethics, exegesis, and philosophy: Interpretation after Levinas. New York: Cambridge University Press.

Delf, H. (1993). “Indiesem Meer von Zeiten, meineZeit!” Eine Skizzezu Leben und Denken der Margarete Susman (In this sea of times, “my time!” A sketch of the life and thought of Margarete Susman). In J. Dick and B. Hahn (Eds.), Von einer Welt in die andere: Jüdinnenim 19. und 20. Jahrhundert (From one world to another: Jewish women in the 19th and 20th centuries) (pp. 248-265). Vienna: Brandstätter.

Donoghue, D. (1981). Ferocious alphabets. London: Faber.

Ebeling, G. (1959). Hermeneutik. Religion in Geschichte und Gegenwart, 3, 243-262.

Eaglestone, R. (1977). Ethical criticism—Reading after Levinas. Edinburgh: Edinburgh University Press.

Haezrachi, P. (1954). Contemplative activity. London: George Allen \& Unwin.

Haezrachi, P. (1961). The price of morality. London: George Allen \& Unwin. 
Heidegger, M. (2010). The origin of the work of art. In Basic writings: Martin Heidegger. London: Routledge.

Herzog, A. (2005). Levinas, memory, and the art of writing. Philosophical Forum, 36(3), 333-343.

Iser, W. (1978). The act of reading: A theory of aesthetic response. Baltimore and London: Johns Hopkins University Press.

Kröger, U. (2004). Zürich, du meinblaues Wunder (Zurich, my blue wonder). In Literarische Streifzüge Durch Eine Europäische Kulturstadt (Literary rambles through a European city of culture) (pp. 427-428). Zürich: Limmat.

Leibowitz, Y. (1974). Fear of god in the book of job. TureiYeshurun, 41, 7-9, 39.

Leibowitz, Y. (1975). The fear of god in the book of Genesis and in the book of job. In Judaism, the Jewish people, and the state of Israel (pp. 393-394). Jerusalem: Schocken.

Leibowitz, Y. (1995). Experience and the fear of god in the book of job. In L. Mazor (Ed.), Job in the Bible (pp. 34-42). Jerusalem: Hebrew University.

Levinas, E. (1989). Reality and its shadow. In S. Hand (Ed.), The Levinas reader (pp. 130-143). Oxford: Basil Blackwell.

Levinas E. (1994). Beyond the verse: Talmudic readings and lectures. (G. D. Mole, Trans.). Bloomington, IN: Indiana University Press.

Levinas, E. (1996). Paul Celan: From being to the other. In Proper names. Stanford: Stanford University Press.

Levinas, E. (2011). Otherwise than being. (A. Lingis, Trans.). Pittsburgh: Duquesne University Press.

Levinas, E. (1994). La réalité et son ombre (Reality and its shadow). In Les imprévus de l'histoire (The unexpected of the history) (pp. 123-148). Montpellier: Fata Morgana.

Levy, Z. (1976). Structuralism: Between method and theory. Tel Aviv: Sifriat Poalim.

Levy, Z. (1986). Hermeneutics. Tel Aviv: Sifriat Poalim.

Levy, Z. (1990). On the status of aesthetics in Jewish philosophy. In D. Cassuto (Ed.), Art and Judaism (pp. 83-103). Ramat Gan: Bar Ilan University.

Levy, Z. (1996). Something wicked and egoistic and cowardly in artistic enjoyment. Studio, 69, 48-51.

Levy, Z. (1997).The other and responsibility. Jerusalem: Magnes Press.

Levy, Z. (2006). Hermeneutics in modern Jewish thought. Jerusalem: Magnes Press.

Lyotard, J. F. (2002). The differend: Phrases in dispute. Minneapolis: University of Minnesota Press.

Malagoli, R. (1993). Margarete Susman und der deutsch-jüdische Dialog (Margarete Susman and the German-Jewish dialogue). Conditio Judaica, III, 351-362.

Mazor, L. (Ed.). (1995). Job in the bible, philosophy, and the arts: A conference of the department of bible study. Jerusalem: Hebrew University of Jerusalem, 1992/93. Jerusalem: Magnes Press.

Meir, E. (2002-2004). On the people of the book and multiple interpretations. Hagut-Jewish Educational Thought, 5-6, 53-70.

Meir, E (2002). Goethe’s place in Rosenzweig's star of redemption. Daat-A Journal of Jewish Philosophy and Kabbalah, 48, 97-107.

Muller-Vollmer, L. (Ed.). (1989). The Hermeneutic reader. New York: Bloomsbury Academic.

Nemo, P. (1998). Job and the excess of evil. Pittsburgh: Duquesne University Press.

Nordmann, I. (1993). Der Dialog ist Bruch und Beginn: zu Margarete Susman—ein Porträtihres Denkens (the dialogue is broken and starts: to Margarete Susman—a portrait of her thinking). In J. Carlebach (Ed.), Zur Geschichte der jüdischen Frau in Deutschland (On the history of the Jewish woman in Germany) (pp. 203-218). Berlin: Metropol Verlag.

Ophir, A. (2005). The order of evils: Toward an ontology of morals. Cambridge, MA: M.I.T. Press.

Palmer, R. E. (1969). Hermeneutics-Interpretation theory in Schleiermacher, Dilthey, Heidegger, and Gadame. Evanston: Northwestern University Press.

Perry-Lehmann, M. (Ed.). (1992). There was a man in the land of Uz: William Blake's illustrations of the Book of Job (exhibit catalogue). Jerusalem: The Israel Museum.

Plato. (1993). Phaedrus. In The symposium and Phaedrus. Mineoloa, NY: Dover Publications.

Revel-Neher, E. (1995). Descriptions of Job in medieval art. In L. Mazor (Ed.), Job in the bible (pp. 104-113). Jerusalem: Magnes Press.

Sartre, J. P. (2004). Sketch for a theory of the emotions. New York: Routledge.

Schonfeld, E. (2007). The wonder of subjectivity: A Reading of Levinas's philosophy. Tel Aviv: Resling.

Soutet, O. et al. (2010). Le souci de l'art chez Emmanuel Levinas: texts rassemblés et présentés par Danielle Cohen-Levinas (The concern of the art in Emmanuel Levinas: Texts collected and presented by Danielle Cohen-Levinas). Houilles: Manucius.

Susman, M. (1946). Das BuchHiob und das Schicksal des jüdischenVolkes (The Book of Job and the fate of the Jewish people). Zürich: Steinberg Verlag. 
Ueckert, C. (1991). Über Margarete Susman: Annäherung an ein Zentrumohne Peripherie. In A. Herzig (Ed.), Die Juden in Hamburg 1590 bis 1990 (On Margarete Susman: Approaching a center without peripherals) (pp. 263-274). Hamburg: Dölling u. Galitz.

Ueckert, C. (2000). Margarete Susman und Else Lasker-Schüler (Margarete Susman and Else Lasker-Schüler). Hamburg: Dölling u. Galitz.

Wolfskehl, K. (1950). Hiob, oder, die vier Spiegel (Gedichte) (Job, or that four mirrors (poems)). Hamburg: Claassen \& Goverts. Zemach, A. (1989). What did God answer Job. Moznayim, 61/9, 14-17.

Žižek, S. (2002). Welcome to the desert of the real: Five essays on September 11. London: Verso. 